\title{
Do Women have a Choice to Construct their World
}

\author{
Anil Kemal Kaya \\ Eastern Mediterranean University
}

\begin{abstract}
In view of the fact that, the world is not stabile and most of the things change very rapidly. In spite of this, women's place and rights in some fields seem still the same. This paper seeks to explore whether women have any choice to construct their world in their life. This research focuses on analyzing the political economy and the cultural studies perspective to find out some answers for the research questions. Also Berger, Douglas, Foucault and Habermas perspectives have been analyzed to understand better if women have a choice to construct their world. The result points out that, the world can change but to make some changes, awareness of the problem is important. The importance of this paper is to make society aware of inequality rights among genders.
\end{abstract}

Keywords: Women, Labor force, Political rights

\section{Introduction}

Nearly half of the population of the world is women; however they face some inequalities in their life. Therefore, criticizing whether women have a choice to construct their world has to be searched in this highly global environment. Even though both men and women are all human beings, women have no equal right in some fields, such as labor force and political rights, while they are living in the same environment.

By analyzing the political economy and the cultural studies perspective, it is going to be understood that the socialization of males and females, what factors influence women's relative status, what type of role they took for the whole of the history, are all women facing with some inequalities all over the world, what the relation between religion and the women's status in society is, what the role of media for this gender discrimination is, how culture affects this position, who constructs the culture. Beside Berger, Douglas, Foucault and Habermas perspectives have been analyzed to understand better if women have a choice to construct their world. 
This world is socially constructed and it can change too. However to make some changes, people have to be aware that there is a problem in their life (Smythe D.W.,Dinh T.V., p:117,1983); the problem is; unequal rights for men and women in the world. Everything has been constructed around men's world so the critical question here is what should be done for women to construct their world. Since men and women are all human beings they have some needs like "physiological needs", shortly these are the basic needs like food, drinks shelter and sex, "safety needs", like need for security and protection, "belonging and love", people want to belong some groups and being accepted by other people, "self-esteem", need for self respect, reputation, status and "self-actualization", which is the need for "self-fulfillment" (Etzel M.J.,Walker B.J.,Stanton W.J.,p:107 fig:4.3, 2001).

As it is agreed that both genders have same needs, Western and Non Western traditions have argued that male and female have different nature; and biological nature builds the gender differences. Only because males are bodily stronger than females should not give male the right to construct the world around themselves and wait for females to follow their rules (Nussbaum M., Glover J., p: 99, 1995). The questions that has to be asked first is, how men get right to construct the world, restrict what women is going to say, what women is going to wear and what type of roles does woman have? Since men also human beings like women, it can be said that women have the same right as men. Thus women can also have right to give decisions about what she is going to talk about, what she is going to wear and they also have ability to construct their world.

According to Ernestine Frields, who is one of the anthropologists points out that, in primitive societies men and women give equal effort to satisfy the physiological needs of their family and the same things happen in the modern society; both gender share the expenses for their household. However, there is an unequal status among men and women, where men can get all the resources that they need while women just change these resources for a functional form in other words "usable forms" (Blau F. D., Ferber M.A, Winkler A.E., p:17, 1998).

\section{Historical stage: role of women}

To understand better how men get power to construct the world and get right to say what the women's role will be, it should be looked at the history. By doing that it is going to be well understood how these roles have been occurred. During the "primitive times", in other words 
"hunting times", men and women shared their duties. While men were hunting big animals and protect the family; women grew some vegetable and hunted small animals. Hunting big animals gave a man high status in those years. In "horticultural societies" they have grown their own vegetables near their houses, men were preparing the ground for vegetables and continue their behavior of fighting to protect their families and women continue their role in this stage as well, preparing the food and care of the children. During this period of time, men and women have more equal rights, and share duties in comparison to the stage "agricultural societies" which is the next period of "pastoral societies". In "pastoral societies", people started to grow up big animals next to their houses but to feed these animals, men sometimes were far away from their home and in these times it seems that women's role did not change. However during the "agricultural societies", women's roles have been increased in comparison to the role of men. Women's role was to look after the garden and small animals, help their husbands in land, do the housework, and prepare food for their family. On the other hand, men just owned the land and worked on it. As men were the owner of the land they take the decisions on what they are going to do for that land and women had to accept these decisions. During these stages inequality has been occurred among both genders. Men were the head of the family and they were giving the last decision about the things that are related with the family and in these stages it seems that women's roles were bordered within their home. After a time when there was a need for women labor force in the market, young women get an opportunity to work outside the home. During the "industrialization" period women were employed in factories and they did the same jobs as they did in their homes till they get married. When these women get married, they had to stop working because taking care of the children becomes the prior role in their life (Blau F.D., Ferber M.A, Winkler A.E., p: 18-21, 1998).

By looking at these historical stages as mentioned before; people live in patriarchic system, which is male dominated system. In patriarchic system, men control the family institution, what the men say is the rule and it has to be accepted. Also every family member has to respect to the men's ideas and their decisions without any contribution. This seems like a real fact of the world but this is not true because according to Berger's perspective whole of the human's world is socially constructed, nothing is real. In other words people construct the meaning at the beginning of the history and these meanings convert it "as it is" till this century (Osborn R.P., p: 223, 2002). Therefore people reflect all these already learned 
meaning in their behavior. Thus when women take care of the children and prepare food, do all the housework seems like a normal behavior to the people but according to this perspective it can be easily said that women have learned this behavior from early stages, in other words these behaviors or roles come from the primitive societies which they constructed and came till this century (Wuthnow R. HunterJ.D., Bergesen A., Kurzweil E., p: 24-25, 1984).

People from birth till death, learn their behavior like, how they are going to act in their life and continue to teach their children how they are going to act in their future life. It is believed that to teach these behaviors are duties for all parents, they feel that they have to teach these behaviors to be a good mother and to be a good father. They teach different things for two sexes. They buy different toys and talk to them in a different style. This makes gender differentiation. For example, from childhood, mothers teach their daughters how she is going to cook, make a coffee, clean the house because they think that if their daughter doesn't learn all these, she is going to have a big trouble when she gets married; but for boys, they do not need to learn these behavior because in future they are not going to cook, make a coffee or clean the house, their wife is going to do all these works; so when the father comes from his work, he asks his daughter to make a coffee but not his son. The other gender differentiation which is mostly seen is that when girls cry it is taken normal but boys cannot cry too much. When the parents see their sons crying, they say "Do not cry like a girl". By saying that, boys learn that women are weak, they just cry, they cannot do more than crying and if the boys cry as well that means they are weak as women. To show their children that this is real life, father never cries in front of them, and because they want to show that they are strong people no matter what happens they do not cry. These believes are socially constructed; thus people from their childhood, they learn that there is gender discrimination in life and this is so normal (Nussbaum M., Glover J., p: 102, 1995).

"Women are being emotional (more than man). Emotions being opposed to logic (men are logical). An excess of emotions, being undesirable (what ever excess is). Emotions being a weakness (women are weak men are not)"

(Burton G., p: 84-107, 1999).

In the $21^{\text {st }}$ century, gender discrimination affects people's life such as who they are, what they have learned from the other people in the society, what they think about themselves and 
this makes people's life so complicated thus they started to question the things that they believe (Nussbaum M., Glover J., p: 133, 1995).

\section{Importance of symbols}

Traditional male dominant society, typically limits women's right to enter the work environment, like in land or labor which forces for gender division of labor. These limitations sometimes come from religious beliefs, cultural practices and educational system, which gives women a low status in the society. Since in many societies, public institution constructed by men, this creates difficulty for women to work or get a salary with the men. For the reason that women have to talk in the way of men's and think like them to get on well with the men (Sen G., Grown C., p: 26-27.1987).

People live with symbols in their life which controls their behavior; because the symbol has a meaning which is already constructed by the society. When it is said symbols, it can be "sign, images, words or objects that represent something" (Osborn R.P., p: 244, 2002). By looking Douglas perspective it is going to be well understood why people have to behave depending on socially constructed symbols. According to Douglas's perspective, symbols make the differentiation for the nations of the culture and the symbols differentiate the individual one another. "What is clean and dirty depends on a system of classification and the location of matter within that system". In system there are "do's" and "don'ts". "Do's" are the things that they are inside the boundaries that is accepted as a "clean" and "Don'ts" are the things that they are out of the boundaries which is accepted as a "dirty" (Wuthnow R. HunterJ.D., Bergesen A., Kurzweil E., p: 85-86, 1984). Cultures to cultures “do's” and "don'ts” can change. It cannot be seen that each culture sharing the same values. Like in the highly Islamic societies boys and girls cannot play together in their childhood. Girls cannot go outside at night and don't have rights to have a boyfriend; on the other hand boys can go outside whenever they want and they have rights to have a girlfriend. In addition to this, in Islamic countries it is seen that some men do not want their wife work outside the home, that's why some women in this society cannot work outside; if they work that means they are beyond the society system and it is not accepted. No matter if they work or not they have to obey their husbands' rules (Poya M. p: 110, 1999). The people who do not obey the norms, in other words people who beyond the system boundaries are punished" (Wuthnow R. HunterJ.D., Bergesen A., Kurzweil E., p: 88, 1984). 
In Islamic countries married women have higher status than the single women and "virginity is the symbol of the family and husband's honor" (Poya M. p: 110, 1999). That's why women cannot have more than one boyfriend in their life. If they have one boyfriend, she has to marry to this man to be inside the boundary system. When man and woman get married, at the wedding night, man understands if his wife is virgin or not. As "virginity is the symbol for honor", if the man understands his wife is not virgin that means he has right to divorce his wife. That means she is dishonest in other words "dirty" or "not pure" and she is beyond the society system, which is not accepted. Also married woman cannot love another man and has a relationship. If she has, her husband directly divorces her or in some situations kills her to protect his honor. When the man kills his wife due to that reason is just because he believes that he has to punish her. For the reason as it mentioned earlier she is dishonest and dishonesty is not accepted in society. In this situation the women who got divorced from her husband cannot go back to her parent's home because they also reject her. On the other hand when married man get a relationship with other woman, especially if his wife does not work outside, in other words if she does not earn money, she has to accept this situation because she depends on her husband economically. That's why her husband feels himself more powerful and does whatever he wants freely. Men expect to be the first men in their wife's life but women cannot expect the same thing because they are men and whatever they do is right.

\section{Power in society}

Power in the society is an important aspect, where Foucault perspective clearly explains it. According to Foucault perspective, power in the societies comes for knowledge of the society (Wuthnow R. HunterJ.D., Bergesen A., Kurzweil E., p: 134, 1984). When it looked at the previous years it can be seen that number of educated men are more than the number of educated women. Thus there was a knowledge gap between men and women, which makes women less powerful than men. Parents in some nations do not send their daughter to school because they believe that girls do not need to go to school; they have specific roles like doing some housework, preparing food if they have brother or sister care of them till the age of marriage. When they're married, her husband will go to work outside and bring money at home; this makes women dependent on men. Men can give a decision, can put some rules and women's has to follow her husband rules. In that type of society, since women has no 
education they have no knowledge about the world so what her husband say is right for them, even they do not try to think what he is talking about. When the parents have two children one girl and one boy, boys can go school because in future they have to take care of his family and girls have to stay at home. For this reason it can be said that since men are well educated, they have knowledge and they have the power in the society and since the women's are dependent on men; it is difficult for women to construct their own world.

According to Smythe and Dinh; "development in everything is an internal and necessary self movement" (Smythe D.W., Dinh T.V., p: 117, 1983) so neither men nor women can stop the changes, developments are nonstop processes because societies in the world have interaction with each other. They have to bring the technological development in their country otherwise they will be beyond the development. The most important revolution is technological development and this technological development affects whole society in the world. According to Schiller "Technological changes, in other words technological developments make information revolution which starts for capitalist in it never ending pursuit of accumulation is undergoing structural transformation" (Schiller H.I., p:251, 1983). Thus both genders want some changes for their life but introduce a new thing does not mean it is going to be beneficial for them. Capitalism is a good example for this, since technological changes causes to capitalism, both gender expect a beneficial values for that changes but "it causes unemployment in workforce environment" (Schiller H.I., p: 252, 1983). Because of technological change, the owners of the companies bring new technological equipments for their organization; computer can be a good example for this. This revolution affects women to find some space in working environment and they started to be well educated like men. Instead women are also well educated like men they face with some difficulty in finding a higher position job. They are either clerical or they work in service sector (Blau F.D., Ferber M.A., Winkler A.E., p: 27, 1998). At first it can be thought that these technological changes are more beneficial for women because it gives more opportunity to them to work in organizations. However it should not be forgotten that technological changes are more beneficial for the owners of the organization because they can control labor easily so labor for both gender is seen as a "means to ends" like a commodity (Mosco V., p: 237-247, 1983). The owner of the companies use both gender as a labor force to produce their product and sell their product to their customer to earn money no matter if their labor are women or men. The main goal for the owner of the company is how to earn more money so they see their labor 
for both genders as a step to produce their product. It should not be forgotten that power can be change from situation to situation. At first it is seen that the owner of the company has a power in the society but when the labor will not work for this organization, how they are going to produce their product or if they produce the product but with a low quality how they are going to sell their product. Therefore owner of the company has to have a good relationship with their labor; to have a good relationship with them, the owner of the company should not be an autocratic leader they have to ask their labor thought as well. If we think that men are the leader in the family institution, they have to ask women's and children's decision as well before they take a decision, because they are also members of the family and any type of the decision that they are going to take will also affect their life.

"Foucault represented power as exercised rather than possessed as decentralized rather than exercised from the top-down and as a productive rather then repressive" (Sawicki J., p: 52, 1991).

During 1980, women work either clerical or take a place in service sector with a minimum wage but only few of the women has a position in management and after they start their jobs, most of them do not want to stay at home because they want to share household expenses with their husbands (Gurensey J.B., p:44, 1996). While women are thinking like that, to share the household expense, men do not think to share the house works. Still some of them think that these works are women's role so women have to do this.

In this present study, Habermas perspective is so important because this perspective clearly reflects that, there is unbalanced distribution of wealth among men and women. He supports the idea that there is unequal distribution of wealth nation; when it is compared by the women's salary and men's salary, but legitimacy always says that this is normal because men and women have different nature and different responsibility. This is a system; in this system there is inequality; like men and women, where generally men are the managers and women are the subordinates (Wuthnow R. HunterJ.D., Bergesen A., Kurzweil E., p: 217, 1984). There is no freedom for both genders, if the people do not go for their job, they cannot get money and since they cannot earn money they cannot continue their life. This is a system and in this system there is an inequality balance which none of the people want to give up their power because if they give up their power there will be people who are going to take this 
power in their hand. That's why men do not lose their power because if they give up their power women are going to gain this power and they will have to follow the women's role.

\section{Importance of language and media}

Language is another important aspect for the construction of the world and it is constructed by the society. Since men construct their world and expect the women to follow this idioms also represent women as a second class human being, like "a woman has to take place next to her husband's" or "female bird builds a house" all these idioms are constructed by men that show, women have to follow their roles that they learned from their childhood and these things are so normal; it seems these are the nature of the world. When it is looked at the words like women, history (his story), and female the men's domination can be seen easily.

According to Robinson, Chicagoans School thought that media get an important role for the public life after this technological development. It is type an "information source for society" therefore both genders get an information for the media. (Robinson G.J., p: 103, 1988).

Since most of the people in the world want to live in a "democratic society"; it is difficult to see "democracy" in the society and to live in "democratic society become a main goal for whole of the society in the world, because still men talk in important aspects of life and get a critical decision alone; on the other hand women just accept what already decided. However for the "democratic society", both genders have to have equally participation for a critical aspect for the life. The critical aspects which is already taken by the men do not show that whole the women agree with the argument. It cannot be seen any women's thought in critical aspects, like political issues or any economic issues, that's why it became a "dragon" (Robinson G.J., p: 97, 1988). It cannot be known what women think about these aspects; because women thought is never asked. Hence to live in "democratic society" both gender have to have equal rights that's why there must be "radical changes" for the society (Smythe D.W.,Dinh T.V., p:118,1983).

Information revolution increases the importance of media in the society. Since media spread all the information what is happening all over the world has a power because they told the people what they are going to believe, how they are going to act and what they are going to talk about. They are setting the agenda to protect the statuesque (Mosco V., 1983). In most 
programs that are basically seen in media for women are about health or music programs, it cannot be seen any women in a discussion program for the critical aspects about life. Since both gender live in the same environment and since females can also give a way for their life why just men are discussing in the discussion programs and not seen any women? (Robinson G.J., p"103, 1988)

"Advertisements, TV programs and feature films play pivotal role in organizing the images and discourses through which people make sense of the world” (Golding P. Murdock G. p: 15, 1992).

To understand this it should be asked "who owns the media and who controls it", because the person who owns media has a right to construct their reality. Since mostly men own the media, they construct their reality. When it is looked at the TV programs and advertisements it can be easily seen that there is gender discrimination. There are some programs for women and some programs for men; women's programs are displayed during the "day time" and men's programs are displayed in "prime time". Therefore the media owner decides the content of women's and men's programs. This gender discrimination is also seen in the advertisements as well. Advertisers use women when they are going to make advertisement for household product like a woman who is cooking or cleaning the house, and this displays the role of women, although men can also cook and clean the house, it cannot be seen any men who is cooking and who is cleaning the house in the advertisements or it cannot be seen any violent women in TV because the other women are going to recognize that, the other women are also facing with the same situation and they can join their forces, these make men to keep continue to control women, what they are doing and how they are thinking, not to lose their power in the society (Golding P., Murdock G., p:15-31, 1992).

\section{Conclusion}

As it was mentioned earlier, men and women have some position in public place and they are partners but when they get back their home, men do not share the house works with their partner; they believe that when they turn their home they finished their responsibilities. Since both genders are human being and there must be equal rights for them. It should be remembered that, gender roles are socially constructed there is no specific role for each gender in their life. As it was mentioned earlier, to live in a "democratic society" which is the main aim for all societies, both gender have to have equal rights that's why people in the 
society have to be open for "radical changes" because, people in the society cannot avoid the social changes.

This world is socially constructed and it can change as well, but to make some changes, people have to be aware that there is a problem in their life.

\section{Reference}

Blau F.,D., Ferber M.,A, Winkler A.,E., (1998), The Economics of Women, Men and Work, $3^{\text {rd }}$ edition, Prentice Hall, USA

Burton G., (1999), Representation Race and Youth Culture in Media and Popular Culture, Hodder\& Stoughter, London

Etzel M.J.,Walker B.J.,Stanton W.J., (2001), Marketing, $12^{\text {th }}$ edition, McGrawhill, New York

Golding, P. \& G. Murdock (1992). "Culture, communication and political economy”, in Golding, P. \& M. Gurevitch (ed) Mass Media and Society. NY.

Gurensey J.B., (1996), Voices of Feminism, 1996, Lerner Publication company

Mosco V., (1983), "Critical Research and the Role of Labor," Journal of Communication (Summer, 1983), p. 237-248.

Nussbaum M., Glover J., (1995), Women culture and Development, Clarendon Press, Oxford

Osborn R., (2002), Mega words 200 terms you really need to know, Sage publication, London

Poya M., (1999), Women Work and Islam, New York

Robinson, G. J. (1988). "Here be dragons:" Problems in charting the U. S. history of communication studies. Communication, $\underline{10}$, 97-119.

Sawicki J., 1991, Disciplining Foucault Feminism, Power and Body, published in Great Britain, USA

Schiller H.I, (1983), Critical Research In The Information Age, Journal of Communication Vol: 33 iss: 3 p. $249-257$

Sen G., Grown C., (1987), Development Crises and Alternative Vision, published in the USA by Monthly Review Press

Smythe, DW, \& Dinh, TV (1983). On critical and administrative research: A new critical analysis. Journal of Communication, Vol: 33 Iss: 3, p. 117-127 
Wuthnow R. HunterJ.D., Bergesen A., Kurzweil E., (1984), Cultural Analysis, Routledge, London and New York 